\title{
KORELASI KOMPOSISI UNSUR TERHADAP SIFAT TERMAL SERBUK BAHAN BAKAR U-ZrHx
}

\author{
Masrukan K, M Husna Alhasa, Yanlinastuti \\ Pusat Teknologi Bahan Bakar Nuklir-BATAN \\ Kawasan Puspiptek, Serpong, Tangerang Selatan, 15314 \\ e-mail: masrukan2006@yahoo.com \\ (Naskah diterima : 19-04-2016, Naskah direvisi: 16-05-2016, Naskah disetujui: 23-05-2016)
}

\begin{abstract}
ABSTRAK
KORELASI KOMPOSISI UNSUR TERHADAP SIFAT TERMAL SERBUK BAHAN BAKAR

$\mathbf{U}-\mathbf{Z r H}_{\mathbf{x}}$. Telah dilakukan analisis untuk menentukan korelasi komposisi terhadap sifat termal pada serbuk bahan bakar $\mathrm{U}-\mathrm{ZrH}_{\mathrm{x}}$. Serbuk $\mathrm{U}-\mathrm{ZrH}_{\mathrm{x}}$ dibuat dari proses hidriding ingot $\mathrm{U}-\mathrm{Zr}$, dimana ingot $\mathrm{U}-\mathrm{Zr}$ merupakan hasil peleburan logam $\mathrm{U}$ dan $\mathrm{Zr}$. Dalam percobaan ini dibuat tiga variasi serbuk yaitu U-35ZrH, $\mathrm{U}-45 \mathrm{ZrH}_{\mathrm{x}}$, dan U-55ZrH $\mathrm{Zn}_{\mathrm{x}}$. Perlunya dilakukan penentuan kadar $\mathrm{Zr}$ terhadap sifat termal adalah untuk mengetahui pengaruh kadar $Z r$ terhadap sifat transformasi panas dari bahan bakar tersebut. Mula -mula dilebur logam $\mathrm{U}$ dan $\mathrm{Zr}$ didalam tungku peleburan busur listrik hingga menghasilkan ingot $\mathrm{U}-\mathrm{Zr}$. Ingot $\mathrm{U}-\mathrm{Zr}$ selanjutnya dibuat serbuk dengan teknik hidridring-milling hingga menghasilkan serbuk U-Zr. Serbuk U-Zr dianalisis komposisi dengan menggunakan teknik sepektroskopi serapan atom (SAA) dan sepektroskopi UV-Vis. Hasil analisis komposisi menunjukkan bahwa pada analisis untuk menentukan kandungan $U$ dan $\mathrm{Zr}$ hampir semua sampel uji yang dianalisis mempunyai perbedaan yang cukup besar antara kandungan $U$ dan $\mathrm{Zr}$ yang ditentukan dengan hasil analisis $U$ dan $\mathrm{Zr}$ terkecuali hasil analisis pada serbuk $\mathrm{U}-45 \mathrm{Zr}$ yang hanya berbeda 0,609 \%. Dari hasil pengujian unsur pengotor diperoleh bahwa semua unsur pengotor yang ada masih memenuhi persyaratan untuk bahan. Pengujian kapasitas panas yang dilakukan pada rentang temperatur $35^{\circ} \mathrm{C}$ hingga $437^{\circ} \mathrm{C}$ memperlihatkan bahwa nilai kapasitas yang paling besar adalah serbuk $\mathrm{U}-35 \mathrm{ZrH}_{\mathrm{x}}$ dengan nilai kapasitas panas sebesar $0,13 \mathrm{~J} / \mathrm{g} .{ }^{\circ} \mathrm{C}$. Sementara itu dari pengujian transisi perubahan fasa diperoleh bahwa pada $U-45 \mathrm{ZrH}_{\mathrm{x}}$ mengalami dua tahapan reaksi disertai perubahan fasa. Dapat disimpulkan apabila dilihat dari kandungan $U$ dan $\mathrm{Zr}$ belum bisa digunakan untuk bahan bakar, sedangkan dari analisis kandungan unsur pengotor diperoleh bahwa semua unsur yang ada masih memenuhi persyaratan untuk bahan bakar kecuali unsur Fe. Sementara itu hasil analisis sifat termal yaitu kapasitas panas diperoleh nilai kapasitas panas tertinggi pada serbuk $\mathrm{U}-35 \mathrm{ZrH}_{\mathrm{x}}$, sedangkan dari pengujian transisi perubahan fasa diperoleh bahwa pada $\mathrm{U}-45 \mathrm{ZrH}_{\mathrm{x}}$ mengalami dua tahapan reaksi disertai perubahan fasa. Terdapat pengaruh komposisi terhadap sifat termalnya, dimana semakin tinggi kandungan Zr maka nilai kapaistas panas hidrida uranium zirkonium semakin rendah.
\end{abstract}

Kata kunci: komposisi, sifat termal, bahan bakar, $\mathrm{U}-\mathrm{ZrH}_{\mathrm{x}}$. 


\section{ABSTRACT}

COMPOSITION CORRECTION ON THE THERMAL PROPERTIES OF U-ZrHx FUEL POWDERS. Analysis has been conducted to determine the composition correlation on the thermal properties of the powder fuel $U-Z r H x$. U-ZrHx powder made from the process hidriding $U$ $\mathrm{Zr}$ ingot, where the ingot is the result of $\mathrm{U}-\mathrm{Zr}$ and $\mathrm{Zr} U$ metal melting. In this experiment made three variations of powders, namely U-35ZrHx, U-45ZrHx, and U-55ZrHx. Need for determination of the thermal properties of $\mathrm{Zr}$ was to determine the effect of the nature of the transformation of $\mathrm{Zr}$ levels of heat from the fuel. At first, $U$ and $Z r$ metal is melted in electric arc furnaces to produce ingot U-Zr. U-Zr ingot then made powder with hidridring-milling techniques to produce $U-Z r$ powder. U-Zr powder composition analyzed using techniques sepectroscopy atomic absorption (AAS) and UV-Vis spectroscopy. The results of composition analysis showed that the analysis to determine the content of $U$ and $Z r$ nearly all the test samples analyzed have quite a big difference between the content of $U$ and $Z r$ as determined by the results of the analysis of $U$ and $Z r$ exception analysis result in powder U-45Zr which differ only $0.609 \%$. From the analysis of impurities obtained that nearly all the impurities that exist still meet the requirements for fuel unless the elements $\mathrm{Fe}$, where elements of the existing $\mathrm{Fe}$ amounted to $382.912 \mathrm{~g} / \mathrm{g}$ while the requirement of $\leq 250 \mathrm{mg} / \mu \mathrm{g}$. Testing conducted heat capacity in the temperature range $35^{\circ} \mathrm{C}$ to $437^{\circ} \mathrm{C}$ showed that the capacity were greatest powder $35 \mathrm{ZrH} \mathrm{H}_{x} \mathrm{U}$-with a value heat capacity of $0.13 \mathrm{~J} / \mathrm{g} .{ }^{\circ} \mathrm{C}$. Meanwhile, test results obtained transition phase change that the U-45ZrHx undergo two stages of reaction with phase change. It can be concluded when seen from the content of $U$ and $\mathrm{Zr}$ can not be used for fuel, while the analysis of the content of impurities found that all the elements that are still eligible for the fuel unless the element Fe. For the analysis of the thermal properties are the heat capacity of the heat capacity of the highest values obtained in powder $\mathrm{U}-35 \mathrm{ZrHx}$, while the transition from the testing phase changes shows that the U-45ZrHx undergo two stages of reaction with phase change. There is an effect of the composition on the thermal properties, where the higher the content of $Z r$, the value of uranium zirconium hydride heat capacity is lower.

Keywords: composition, thermal properties, fuels, U-ZrHx. 


\section{PENDAHULUAN}

Pengembangan bahan bakar reaktor riset dan daya tengah dilakukan di Pusat Teknologi Bahan Bakar Nuklir (PTBBN) dalam rangka mendapatkan bahan bakar yang mempunyai densitas tinggi. Pengembangan bahan bakar rekator daya ditujukan untuk memperoleh bahan bakar prototype elemen bakar PWR dan berkas bahan bakar HWR/Cirene sedangkan untuk reaktor riset memperoleh bahan bakar berdensitas tinggi dari paduan U-Mo, U-Zr dan U-N ${ }^{[1]}$. Bahan bakar reaktor PWR dapat berupa bahan bakar keramik, logam, hidrida atau campuran antara keramik dengan logam. Penggunaan bahan bakar paduan $\mathrm{U}-\mathrm{Zr}$ telah lama digunakan secara luas, seperti untuk bahan bakar reaktor TRIGA (Training Isotop by General Atomic) dalam bentuk U-ZrH $\mathrm{r}_{\mathrm{x}}$ ABWR (Advance Boiling Water Reactor), FBR (Fast Bredeer Reaktor) dan EBR (Experiment Breeder Reactor) dimana bahan bakar tersebut dibuat dalam bentuk campuran antara $U$, $\mathrm{Pu}$ dan $\mathrm{Zr}^{[2]}$. Penelitian pembuatan bahan bakar berbasis $\mathrm{U}-\mathrm{Zr}$ telah dikembangkan di PTBBN sejak tahun 2007 yaitu dengan membuat bahan bakar $\mathrm{U}-\mathrm{Zr}$ untuk jenis reaktor riset sedangkan paduan uranium hidrida $\left(\mathrm{U}-\mathrm{ZrH}_{\mathrm{x}}\right)$ dikembangkan untuk jenis reaktor daya PWR melalui kerjasama antara BATAN dengan Kementerian Riset dan Teknologi (Kem Ristek) dari tahun 2012 dalam progam Peningkatan Kemampuan Peneliti dan Perekayasa (PKPP) ${ }^{[3]}$. Dalam percobaan ini dilakukan pengembangan bahan bakar hidrida $\mathrm{U}-\mathrm{ZrH}_{\mathrm{x}}$ untuk reaktor PWR dengan pertimbangan-pertimbangan bahwa bahan bakar $\mathrm{U}-\mathrm{ZrH}_{\mathrm{x}}$ dapat menempatkan hidrogen sebagai moderator secara langsung di dalam bahan bakar yang memungkinkan reaktor dapat beroperasi pada temperatur yang relatif tinggi (hingga $750^{\circ} \mathrm{C}$ ) serta mempunyai sifat termal lebih baik [4]. Penelitian yang dilakukan ini dimaksudkan untuk mengetahui pengaruh kandungan unsur di dalam $\mathrm{U}-\mathrm{ZrH}_{\mathrm{x}}$ terhadap kapasitas panas serta transisi perubahan fasa.

Untuk dapat digunakan sebagai bahan bakar nuklir, paduan $\mathrm{U}-\mathrm{ZrH}_{\mathrm{x}}$ tersebut harus mempunyai kemurnian yang tinggi dan sifat termal yang cukup baik. Hal ini disebabkan bila di dalam bahan bakar terdapat banyak unsur pengotor maka unsur tersebut dapat membentuk senyawa yang akan mengurangi unjuk kerja bahan bakar tersebut bila digunakan di dalam reaktor. Demikian pula bahan bakar harus mempunyai sifat termal (titik lebur dan kapasitas panas) yang cukup baik/tinggi agar tranformasi panas di dalam bahan bahan bakar dapat berlangsung lebih cepat. Beberapa teknik dapat digunakan untuk menentukan kandungan unsur di dalam suatu bahan, diantaranya dengan menggunakan teknik Spektroskopi Serapan Atom (SSA), Inductively Coupled Plasma Atomic Emission Spectrometer (ICP-AES) Plasma 40, X Ray Flourocency (XRF), dan UV-Vis. Teknik SSA dan ICP-AES biasanya digunakan untuk menentukan unsur pengotor di dalam suatu bahan, teknik UVVis untuk menentukan kadar uranium sedangkan $X$-Ray Fluoresensi (XRF) merupakan salah satu teknik analisis tidak merusak digunakan untuk analisis unsur dalam bahan secara kualitatif dan kuantitatif ${ }^{[5]}$.

Kandungan unsur-unsur pengotor dalam bahan bakar nuklir perlu diketahui macam dan jumlahnya dan harus memenuhi persyaratan/spesifikasi yang ditentukan untuk bahan bakar, karena keberadaan unsur pengotor dapat mengganggu proses yang terjadi dalam reaktor. Unsur logam pengotor dapat berasal dari logam pemadu atapun dari logam induknya/ yang dipadu. Untuk bahan bakar reaktor jenis PWR, persyaratan utama kandungan unsur-unsur pengotor dapat dilihat seperti tertera pada Tabel 1. Sebagai bahan bakar nuklir, logam $U$ mempunyai sifat-sifat yang terbatas sehingga perlu ditambah dengan unsur 
logam pemadu. Penambahan unsur pemadu ke dalam logam murni dengan tujuan antara lain sebagai berikut:[3]

a. Mendapatkan ukuran butir yang halus,

b. Menaikkan sifat mekanik,

c. Mempertahankan fasa beta atau gamma $U$ pada temperatur operasi reaktor,

d. Melarutkan $U$ yang diperkaya,

e. Menahan lapisan difusi $U$ dengan material kelongsong,

f. Membuat elemen bakar tipe dispersi secara teknik langsung atau membuat elemen bakar dispersi dengan teknik metalurgi serbuk

g. Menaikkan mampu cor (castability) bahan bakar hasil cor.

Tabel 1. Spesifikasi kandungan unsur-unsur pengotor di dalam bahan bakar PWR ${ }^{[6,7]}$

\begin{tabular}{|l|c|l|l|}
\hline No. & Unsur & $\begin{array}{c}\text { Kadar } \\
((\mu \mathrm{g} / \mathrm{g})\end{array}$ & $\begin{array}{c}\text { Nilai boron } \\
\text { ekivalen }\end{array}$ \\
\hline 1. & $\mathrm{Al}$ & $\leq 250,0$ & 0,00012 \\
\hline 2. & $\mathrm{Ca}$ & $\leq 200,0$ & 0,00016 \\
\hline 3. & $\mathrm{Cd}$ & $\leq 0,2$ & 0,31044 \\
\hline 4. & $\mathrm{Co}$ & $\leq 100,0$ & 0,00899 \\
\hline 5. & $\mathrm{Cr}$ & $\leq 200$ & 0,00083 \\
\hline 6. & $\mathrm{Cu}$ & $\leq 250,0$ & 0,00085 \\
\hline 7. & $\mathrm{Fe}$ & $\leq 250,0$ & 0,00065 \\
\hline 8. & $\mathrm{Mg}$ & $\leq 50$ & 0,00004 \\
\hline 9. & $\mathrm{Mn}$ & $\leq 250,0$ & 0,0343 \\
\hline 10. & $\mathrm{Mo}$ & $\leq 250,0$ & 0,00376 \\
\hline 11. & $\mathrm{Ni}$ & $\leq 200,0$ & 0,00107 \\
\hline 12. & $\mathrm{~Pb}$ & $\leq 250,0$ & 0,000746 \\
\hline 13. & $\mathrm{Si}$ & $\leq 300,0$ & 0,00086 \\
\hline 14. & $\mathrm{Sn}$ & $\leq 250,0$ & 0,00027 \\
\hline 15. & $\mathrm{Zn}$ & $\leq 250,0$ & 0,00024 \\
\hline 16. & $\mathrm{~B}$ & $\leq 10,0$ & 1,0000 \\
\hline
\end{tabular}

Selain mempunyai kemurnian yang tinggi, bahan bakar harus mempunyai sifat termal (perubahan fasa, entalpi dan kapasitas panas) yang cukup baik. Sifat termal merupakan kunci utama untuk mendesain dan mengoptimalisasi temperatur di dalam teras reaktor ${ }^{[8]}$. Kapasitas panas menggambarkan sejumlah panas yang diperlukan untuk mengubah temperatur bahan bakar. Dengan mengetahui kapasitas panas bahan bakar sebagai fungsi temperatur dan apabila nilai kapasitas panasnya tinggi dapat membantu stabilitas bahan bakar karena panas tidak terakumulasi di dalam bahan bakar sehingga dapat memperkecil kemungkinan kerusakan bahan bakar. Perubahan energi biasanya menyebabkan perubahan panas dalam suatu bahan yang disebut dengan panas reaksi. Dapat dipahami bahwa panas setara dengan kerja sehingga panas merupakan suatu bentuk energi. Dengan demikian dapat diartikan bahwa panas reaksi adalah perubahan energi yang menyertai suatu reaksi kimia atau fisis dalam suatu bahan. Ada dua jenis sifat yang terkait dengan reaksi kimia atau reaksi fisis dalam suatu bahan yaitu panas jenis dan kapasitas panas. Panas jenis adalah jumlah panas yang dibutuhkan untuk menaikkan temperatur $1^{\circ} \mathrm{C}$ terhadap $1 \mathrm{~g}$ zat. Panas jenis dinyatakan sebagai suatu besaran: $q=m x c x$ $\Delta \mathrm{T}$, dengan $\mathrm{q}$ adalah panas yang diserap atau yang dilepas (Joule atau calori), $m$ adalah massa (g) , c adalah panas jenis $\left(\mathrm{J} / \mathrm{g}^{\circ} \mathrm{C}\right)$, dan $\Delta \mathrm{T}$ adalah perubahan tempe$\operatorname{ratur}\left({ }^{\circ} \mathrm{C}\right)$. Untuk kapasitas panas, secara umum dapat didefinisikan sebagai jumlah panas yang dibutuhkan untuk menaikkan temperatur bahan sebesar $1^{\circ} \mathrm{C}$ yang dinyatakan dengan rumus sebagai berikut : $\mathrm{q}=$ $\mathrm{Cp} \times \Delta \mathrm{T}$, dengan $\mathrm{q}$ adalah panas yang diserap atau dilepas (Joule atau calori ), Cp adalah kapasitas panas cal atau Joul/ ${ }^{\circ} \mathrm{C}$, dan $\Delta \mathrm{T}$ adalah perubahan tempe-ratur $\left({ }^{\circ} \mathrm{C}\right)$, Dari rumusan diatas terlihat bahwa besaran kapasitas panas sangat dipenga-ruhi oleh jenis bahan dan temperatur ${ }^{[9]}$.

\section{METODOLOGI}

Serbuk $\mathrm{U}-\mathrm{ZrH}_{\mathrm{x}}$ dibuat dari ingot $\mathrm{U}-\mathrm{Zr}$ (U-35Zr), (U-45Zr) dan (U-55Zr) dimana ingot $U-Z r$ dibuat dari peleburan logam $U$ dengan logam Zr. Pembuatan serbuk U-Zr dilakukan dengan cara hidriding di dalam 
peralatan hidriding dengan cara dipanaskan pada temperatur $350^{\circ} \mathrm{C}$ sambil divakum hingga mencapai kevakuman $10^{-6}$ Psi kemudian dialiri gas hidrogen. Serbuk yang diperoleh dibagi menjadi dua, sebagian dianalisis untuk penentuan komposisi unsur logam dan sebagian yang lain untuk analisis termal. Penentuan komposisi unsur yang dilakukan adalah menentukan kandungan unsur pengotor, kandungan $\mathrm{U}$ dan $\mathrm{Zr}$. Kandungan unsur logam pengotor, dilakukan dengan menggunakan teknik spektroskopi serapan atom (SSA) sedangkan kandungan unsur $U$ menggunakan teknik spektroskopi UV-Vis. Sampel uji untuk analisis menggunakan UV-Vis harus dibuat dalam bentuk larutan/cair dengan cara melarutkan ke dalam larutan campuran larutan $\mathrm{HNO}, 3 \mathrm{M}$ dan $\mathrm{HF} 1 \mathrm{M}$ dengan perbandingan 1: 1. Sementara itu, untuk penentuan kapasitas panas digunakan teknik Differential Scanning Calorimetry (DSC) dan perubahan fasa serta temperatur lebur menggunakan Differential Termal Analysis (DTA). Pada pengujian DSC, sampel berbentuk serbuk dengan berat $0,5 \mathrm{~g}$ dimasukkan ke dalam cawan kecil kemudian dimasukkan ke dalam sampel holder DSC dan siap dioperasikan. Pengujian DSC dilakukan dari temperatur $35^{\circ} \mathrm{C}$ hingga $450^{\circ} \mathrm{C}$, sedangkan pengujian dengan DTA dilakukan dari temperatur $30^{\circ} \mathrm{C}$ hingga $1000^{\circ} \mathrm{C}$.

\section{HASIL DAN PEMBAHASAN}

\section{a. Komposisi Unsur}

Hasil analisis komposisi unsur dengan menggunakan SSA dan UV-Vis ditampilkan dalam Tabel 2 dan 3. Tabel 2 yang memuat hasil analisis kandungan $\mathrm{U}$ dan $\mathrm{Zr}$ menunjukkan bahwa hampir semua sampel uji yang dianalisis mempunyai perbedaan yang cukup besar antara yang direncanakan dengan hasil uji kecuali hasil analisis $\mathrm{U}-45 \mathrm{ZrH}_{\mathrm{x}}$ yang hanya berbeda $0,609 \%$. Perbedaan yang cukup besar tersebut disebabkan oleh kekurang sempurnaan/kehomogenan sampel pada proses pelarutan dan pemisahan larutan saat proses ekstraksi untuk memisahkan $\mathrm{U}$ dan $\mathrm{Zr}$ sehingga pada bagian tertentu terdapat unsur $U$ atau $\mathrm{Zr}$ yang berlebihan yang pada akhirnya akan mempengaruhi hasil pengujian. Ketidak sempurnaan dapat terjadi pada saat pengadukan, pemisahan antara fasa organik dan fasa air atau dapat juga pada saat penambahan zat pelarut $\mathrm{HNO}_{3}$ yang tidak tepat. Kesalahan dapat juga terjadi pada saat melakukan running peralatan uji penentuan $U$ atau $\mathrm{Zr}$ (UV-Vis). Apabila dilihat dari hasil penimbangan bahan baku $\mathrm{U}$ dan $\mathrm{Zr}$ serta ingot yang terjadi dari hasil proses peleburan terlihat hampir semua sampel mem-punyai prosen berat yang tidak berbeda jauh dengan prosen berat yang diren-canakan seperti tertera pada Tabel 1, 2 dan 3 dalam Lampiran. Oleh karena itu selain proses running peralatan uji, pada saat proses penyiapan sampel harus benarbenar dilakukan dengan sangat hati-hati karena proses ini akan sangat menentukan hasil uji. Apabila dilihat dari kandungan $\mathrm{U}$ dan $\mathrm{Zr}$ yang ada sampel tersebut belum bisa digunakan untuk bahan bakar. 
Tabel 2. Hasil analisis kandungan $\mathrm{U}$ dan $\mathrm{Zr}$

\begin{tabular}{|c|c|c|c|c|c|c|c|c|c|c|}
\hline \multirow[t]{3}{*}{ zo } & 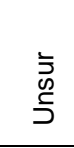 & \multicolumn{6}{|c|}{ Konsentrasi } & \multicolumn{3}{|c|}{$\begin{array}{c}\text { Selisih antara yang } \\
\text { direncanakan dengan hasil } \\
(\%)\end{array}$} \\
\hline & & & encanakan & & & Hasil (\%) & & & & \\
\hline & & U-35ZrH & U- $45 \mathrm{ZrH}_{\mathrm{x}}$ & U-55ZrH & U- $35 \mathrm{ZrH}_{\mathrm{x}}$ & U- $45 \mathrm{ZrH}_{\mathrm{x}}$ & U-55ZrH & U-35ZrH & U- $45 \mathrm{ZrH}_{\mathrm{x}}$ & U-55ZrH \\
\hline 1. & U & 65 & 55 & 45 & 56,310 & 50,269 & 41,417 & 13,369 & 8,60 & 7,962 \\
\hline 2. & $\mathrm{Zr}$ & 35 & 45 & 55 & 34,600 & 41,715 & 45,274 & 17,571 & 0.609 & 17,684 \\
\hline
\end{tabular}

Tabel 3 yang memuat hasil analisis unsur pengotor yang ada menunjukkan bahwa pada serbuk U-35ZrH $\mathrm{r}_{\mathrm{x}}$ kandungan unsur $\mathrm{Al}$ hingga $\mathrm{Zn}$ adalah sebesar 0,042 $\mu \mathrm{g} / \mathrm{g}$ (terrendah) hingga 382,912 $\mu \mathrm{g} / \mathrm{g}$ (tertinggi) masing-masing untuk $\mathrm{Cd}$ dan $\mathrm{Fe}$, pada serbuk U-45ZrH $\mathrm{rH}_{\mathrm{x}}$ sebesar $0,101 \mu \mathrm{g} / \mathrm{g}$ (terrendah) hingga 227,136 $\mu \mathrm{g} / \mathrm{g}$ (tertinggi) masing-masing untuk $\mathrm{Cd}$ dan $\mathrm{Al}$, dan pada serbuk U-45ZrH $\mathrm{rH}_{\mathrm{x}}$ sebesar 2,055 $\mathrm{\mu g} / \mathrm{g}$ hingga $206,887 \mu \mathrm{g} / \mathrm{g}$. Dari hasil pengujian tersebut terlihat hampir semua unsur yang ada di dalam serbuk masih memenuhi persyaratan untuk bahan bakar PWR kecuali unsur Fe seperti tertera dalam Tabel 1. Dalam Tabel 1 unsur Fe yang ada sebesar 382,19 $\mu \mathrm{g} / \mathrm{g}$ sedangkan peryaratan yang diijinkan sebesar $250 \mu \mathrm{g} / \mathrm{g}$. Keberadaan unsur Fe yang melebihi dari persyaratan bahan bakar tersebut disebabkan oleh out diffusion dari Fe yang terdapat di dalam wadah/ cawan pada saat proses peleburan masuk ke dalam ingot hasil peleburan sehingga $\mathrm{Fe}$ menjadi besar. Fe yang ada di dalam wadah bisa berasal dari pengotor karena wadah digunakan untuk melebur bahan, atau dapat juga $\mathrm{Fe}$ yang terdapat di dalam wadah itu sendiri. Secara keseluruhan hasil pengujian bila dilihat dari tampang lintang serapan netron mikroskopiknya, terlihat bahwa hampir semua unsur yang ada mempunyai tampang lintang mikroskopik yang rendah kecuali unsur $\mathrm{Cd}$. Unsur $\mathrm{Cd}$ mempunyai tampang lintang netron mikroskopik besar yakni sebesar 2520 barn[1]. Keberadaan unsur yang mempunyai tampang lintang besar dan dalam jumlah yang besar dikhawatirkan akan menyerap neutron yang cukup besar sehingga operasi reaktor bisa terhenti. Namun, dilihat dari jumlah unsur $\mathrm{Cd}$ yang ada hanya sebesar $0,042 \mu \mathrm{g} / \mathrm{g}$ pada U$35 \mathrm{ZrH}_{\mathrm{x}}$ dan $0,101 \mu \mathrm{g} / \mathrm{g}$ pada $\mathrm{U}-45 \mathrm{ZrH}_{\mathrm{x}}$ dimana jumlah tersebut sangat kecil sehingga keberadaan unsur $\mathrm{Cd}$ tidak mempunyai pengaruh yang berarti terhadap operasi reaktor.

Tabel 3. Hasil analisis kandungan unsur pengotor di dalam serbuk U- $\mathrm{ZrH}_{\mathrm{x}}$

\begin{tabular}{|l|c|c|c|c|}
\hline No. & Unsur pengotor & $\begin{array}{c}\text { Sampel } \\
\mathrm{U}-35 \mathrm{ZrH}_{\times}(\mu \mathrm{g} / \mathrm{g})\end{array}$ & $\begin{array}{c}\text { Sampel } \\
\mathrm{U}-45 \mathrm{ZrH}_{\times}(\mu \mathrm{g} / \mathrm{g})\end{array}$ & $\begin{array}{c}\text { Sampel } \\
\mathrm{U}-55 \mathrm{ZrH} \mathrm{H}_{\mathrm{x}}(\mu \mathrm{g} / \mathrm{g})\end{array}$ \\
\hline 1. & $\mathrm{Al}$ & 237,207 & 227,136 & 206,886 \\
\hline 2. & $\mathrm{Ca}$ & 29,665 & 38,273 & 43,007 \\
\hline 3. & $\mathrm{Cd}$ & 0,042 & 0,101 & $\mathrm{ttd}$ \\
\hline 4. & $\mathrm{Co}$ & 0,699 & 0,650 & 2,055 \\
\hline 5. & $\mathrm{Cr}$ & 80,487 & 84,471 & 58,098 \\
\hline 6. & $\mathrm{Cu}$ & 33,822 & 40,519 & 99,192 \\
\hline 7. & $\mathrm{Fe}$ & 382,912 & 119,572 & 186,339 \\
\hline 8. & $\mathrm{Mg}$ & 10,904 & 11,382 & 2,452 \\
\hline 9. & $\mathrm{Mn}$ & 7,926 & 8,805 & 32,946 \\
\hline 10. & $\mathrm{Mo}$ & 40,069 & 78,952 & 111,953 \\
\hline 11. & $\mathrm{Ni}$ & 116,797 & 139,434 & 108,049 \\
\hline
\end{tabular}




\begin{tabular}{|c|c|c|c|c|}
\hline 12. & $\mathrm{~Pb}$ & $\mathrm{ttd}$ & $\mathrm{ttd}$ & ttd \\
\hline 13. & $\mathrm{Si}$ & 214,722 & 170,102 & 206,887 \\
\hline 14. & $\mathrm{Sn}$ & 59,447 & 62,037 & 87,148 \\
\hline 15. & $\mathrm{Zn}$ & 19,181 & 36,227 & 4,171 \\
\hline
\end{tabular}

\section{b. Sifat Termal}

\section{Kapasitas panas}

Pengujian sifat termal menggunakan peralatan DSC untuk mengetahui besar nilai kapasitas panas dari $\mathrm{U}-\mathrm{ZrH}_{\mathrm{x}}$. Untuk memperoleh nilai kapasitas panas maka hasil running dari peralatan DSC dioleh menggunakan rumus Multiple Regresssion dengan pendekatan model Shomate ${ }^{[10]}$ yaitu $\mathrm{Cp}=\mathrm{A}+\mathrm{B} \cdot \mathrm{T}+\mathrm{C} / \mathrm{T}^{2}$, dimana $\mathrm{A}, \mathrm{B}$ dan $\mathrm{C}$ merupakan koefisien yang besarnya masing-masing adalah: untuk $\mathrm{U}-35 \mathrm{ZrH}_{\mathrm{x}}$ nilai A,B, dan C berturut-turut: 0,094855913; 0,000399821; dan -4398,019429. Untuk $\mathrm{U}-45 \mathrm{ZrH}_{\mathrm{x}}$ nilai $\mathrm{A}, \mathrm{B}$ dan berturut-turut adalah 0,07465253; 0,000318441; dan 0; untuk U-55ZrHx nilai A, B dan C 0,146893; 0,000167 , dan 0 . Hasil pengolahan data dari pengujian kapasitas panas ditampilkan dalam Gambar 1. Dalam pengujian tersebut percobaan dilakukan pada rentang temperatur antara $35^{\circ} \mathrm{C}$ hingga $437^{\circ} \mathrm{C}$. Hasil percobaan yang telah diolah datanya memperlihatkan bahwa nilai kapasitas panas antara $\mathrm{U}-35 \mathrm{ZrH}_{\mathrm{x}}, \quad \mathrm{U}-45 \mathrm{ZrH}_{\mathrm{x}}$ dan $\mathrm{U}-55 \mathrm{ZrH}_{\mathrm{x}}$ dalam rentang temperatur tersebut yang terbesar adalah pada $\mathrm{U}-35 \mathrm{ZrH}_{\mathrm{x}}$, diikuti oleh paduan U-45ZrH $\mathrm{ran}_{\mathrm{x}} \mathrm{U}-55 \mathrm{ZrH}$. Dapat dikatakan bahwa semakin besar kandungan $\mathrm{Zr}$, semakin rendah nilai kapsitas panasnya. Sebagai contoh paduan $\mathrm{U}-35 \mathrm{ZrH}_{\mathrm{x}}, \mathrm{U}-45 \mathrm{ZrH}_{\mathrm{x}}$ dan $\mathrm{U}-55 \mathrm{ZrH}$ masing-masing mempunyai kapasitas panas sebesar $0,272323 \mathrm{~J} / \mathrm{g} \cdot{ }^{\circ} \mathrm{C}$; $0,2306 \mathrm{~J} / \mathrm{g} \cdot{ }^{\circ} \mathrm{C}$ dan $0,228884 \mathrm{~J} / \mathrm{g} .{ }^{\circ} \mathrm{C}$ pada temperatur $216,58^{\circ} \mathrm{C}$. Hasil tersebut bersesuaian dengan yang dilakukan oleh Mariea Gruia dkk ${ }^{[11]}$. Hal ini disebabkan semakin besar kandungan $\mathrm{Zr}$ maka hidrida zirkonium $\left(\mathrm{ZrH}_{\mathrm{x}}\right)$ yang terbentuk semakin besar pula.
Perlu diketahui bahwa hidrida zirkonium $\left(\mathrm{ZrH}_{\mathrm{x}}\right)$ mempunyai ikatan kovalen. Dalam ikatan kovalen, ikatan yang terjadi akibat pemakaian bersama pasangan elektron oleh dua atom yang berikatan. Ikatan kovalen terbentuk di antara dua atom yang samasama ingin menangkap elektron (semi logam dan bukan logam). Oleh karena ikatan atom terjadi karena pemakaian pasangan elektron bersama maka elektron tidak mudah bergerak bebas seperti pada ikatan logam, sehingga kemampuan senyawa untuk memindahkan panas menjadi rendah[12]. Untuk bahan bakar nuklir, diharapkan mempunyai kemampuan memindahkan panas dengan baik atau dengan lain kata mempunyai nilai kapasitas panas besar. Dengan melihat kandungan hidrida zirkonium $\left(\mathrm{ZrH}_{\mathrm{x}}\right)$ yang ada dari ketiga paduan, maka bahan bakar padua U-35ZrH mempunyai kemampuan untuk memindahkan panas yang paling baik. Apabila diamati pada setiap termogram paduan serbuk bahan bakar pada Gambar 1 terlihat bahwa dari temperatur pemanasan $35^{\circ} \mathrm{C}$ hingga $437^{\circ} \mathrm{C}$ ketiga paduan serbuk menunjukkan keadaan kecenderungan kenaikan besaran nilai kapasitas panas apabila tempratur pemanasan semakin tinggi, dan kenaikan tertinggi dialami oleh sebuk bahan bakar $\mathrm{U}-35 \mathrm{ZrH}_{\mathrm{x}}$. Hal ini disebabkan panas yang dibutuhkan untuk menikkan temperatur tiap satu derajat setiap satuan massa untuk melakukan vibrasi atom-atom semakin besar apabila temperatur pemanasan semakin tinggi, sedangkan pada kandungan $\mathrm{Zr}$ yang semakin tinggi panas yang dibutuhkan untuk menaikkan temperatur satu derajat setiap satuan massa semakin rendah. 


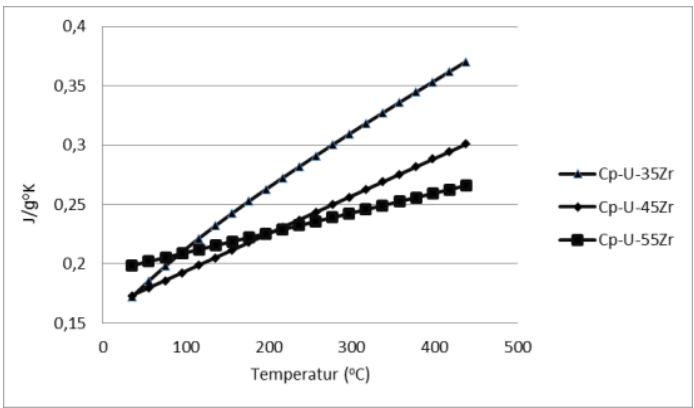

Gambar 1. Termogram hasil pengujian DSC

\section{Transisi Perubahan Fasa}

Hasil pengujian transisi perubahan fasa dan tititk lebur dengan menggunakan peralatan DTA ditampilkan dalam Gambar 2 dan 3 serta Tabel 4. Gamba 2 dan Tabel 4 memperlihatkan keadaan bahwa untuk serbuk $\mathrm{U}-35 \mathrm{ZrH}_{\mathrm{x}}$ tidak terjadi perubahan $\mathrm{U}-45 \mathrm{ZrH}_{\mathrm{x}}$ reaksi pada saat dipanaskan. Untuk serbuk U-45ZrH $\mathrm{Z}_{\mathrm{x}}$ mengalami dua tahapan reaksi yaitu pada tahapan pertama dari temperatur $687,22^{\circ} \mathrm{C}$ hingga $701,13^{\circ} \mathrm{C}$ terjadi reaksi eksotermik dengan melepaskan panas sebesar $-1,060 \mathrm{cal} / \mathrm{g}$ dan terjadi perubahan fasa dari $\beta+\gamma z$ menjadi $\gamma+\gamma z$. Tahapan kedua, dari temperatur $779,51^{\circ} \mathrm{C}$ hingga $803,00^{\circ} \mathrm{C}$ terjadi reaksi endotermik dengan membutuhkan panas sebesar 1,408 $\mathrm{cal} / \mathrm{g}$ disertai perubahan fasa dari $\gamma+\gamma \mathrm{zr}$ menjadi $\gamma z$ r. Hasil tersebut bersesuaian dengan digram fasa $U-Z r^{[13]}$.

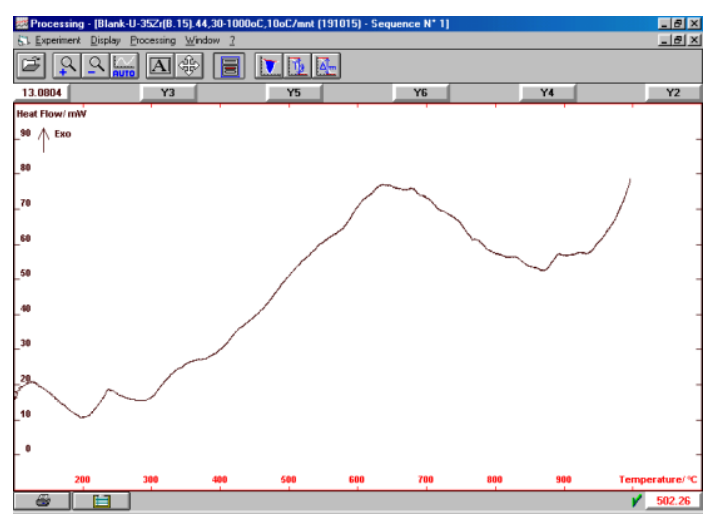

Gambar 2. Termogram hasil pengujian DTA pada $\mathrm{U}-35 \mathrm{ZrH}_{\mathrm{x}}$.

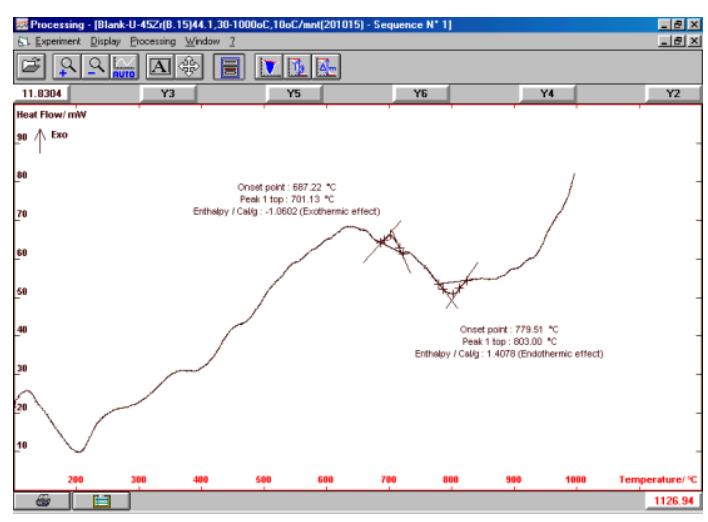

Gambar 3. Termogram hasil pengujian DTA padaU-45Zr

Tabel 4. Hasil transisi perubahan fasa dan pengujian titik lebur

\begin{tabular}{|c|c|c|c|}
\hline Sampel & Enthalphi (Cal/g) & $\begin{array}{c}\text { Titik Lebur } \\
\left({ }^{\circ} \mathrm{C}\right)\end{array}$ & Keterangan (reaksi) \\
\hline $\mathrm{U}-35 \mathrm{ZrH}_{\mathrm{x}}$ & - & - & Tidak terjadi perubahan reaksi \\
\hline $\mathrm{U}-45 \mathrm{ZrH}_{\mathrm{x}}$ & $-1,060$ & 701,13 & Reaksi exotermik \\
\cline { 2 - 4 } & 1,408 & 803,00 & Reaksi endotermik \\
\hline
\end{tabular}

\section{SIMPULAN}

Hasil percobaan analisis untuk menentukan kandungan $\mathrm{U}$ dan $\mathrm{Zr}$ di dalam serbuk $\mathrm{U}-35 \mathrm{ZrH}_{\mathrm{x}}, \quad 35 \mathrm{ZrH}_{\mathrm{x}}$, dan $\mathrm{U}-35 \mathrm{ZrH}_{\mathrm{x}}$ mempunyai perbedaan yang cukup besar, sedangkan dalam analisis kandungan unsur pengotor diperoleh bahwa hampir semua unsur yang ada di dalam paduan serbuk masih memenuhi persyaratan untuk bahan bakar terkecuali unsur Fe. Dengan demikian apabila dilihat dari kandungan unsur $\mathrm{U}$ dan $\mathrm{Zr}$ belum bisa digunakan untuk bahan bakar. Unsur Fe yang ada sebesar 382,912 $\mu \mathrm{g} / \mathrm{g}$ melebihi persyaratan yang hanya $250 \mu \mathrm{g} / \mathrm{g}$. Dilihat dari kandungan $U$ dan $\mathrm{Zr}$, serbuk paduan tersebut belum bisa digunakan untuk bahan bakar nuklir. Sementara itu hasil analisis sifat termal dalam hal ini 
kapasitas panas diperoleh bahwa semakin tinggi kandungan $\mathrm{Zr}$ maka nilai kapasitas panas menjadi semakin rendah, sedangkan dari hasil pengukuran transisi perubahan fasa diperoleh serbuk U-45ZrH $\mathrm{Z}_{\mathrm{x}}$ mengalami dua tahapan reaksi yaitu reaksi eksotermik disertai perubahan fasa dan reaksi endotermik disertai perubahan fasa. Terdapat pengaruh antara komposisi dengan sifat termalnya, dimana semakin tinggi kandungan $\mathrm{Zr}$ maka nilai kapaistas panas hidrida uranium zirkonium semakin rendah.

Perlu dilakukan percobaan ulang untuk memastikan komposisi $\mathrm{U}$ dan $\mathrm{Zr}$ sehingga diperoleh hasil yang tepat sesuai yang direncanakan.

\section{UCAPAN TERIMA KASIH}

Pada kesempatan ini kami mengucapkan terimakasih kepada lbu Asminar ibu Sutri Indaryati dan bapak Yatno D.A yang telah membantu melakukan penelitian hingga selesai. Juga tidak lupa penulis menyampai-kan terima kasih kepada Ibu Ir. Ratih Langenati MT, selaku Kepala BFBBN yang telah mendorong kami sehingga penulisan makalah ini dapat selesai.

\section{DAFTAR PUSTAKA}

[1] Masrukan K, (2011), Komparasi Hasil Analisis Komposisi Kimia Di Dalam Paduan U-Zr-Nb Dengan Menggunakan Teknik XRF dan AAS, Jurnal IImiah Daur Bahan Bakar Nuklir" Urania", Vol 17 No 3, Oktober 2011. ISSN No. 0852-4777. Akreditasi No. 265/AU1/P2MBI/05/ 2010. Hal. 144-145.

[2] Baldev Raj, S L Mannan, Prvasudeva Rao And M D Mathew (2012), Development Of Fuels And Structural Materials For Fast Breeder Reactors, Journal of Sadhana, Vol. 27, Part 5, October 2012, page 531.
[3] Masrukan, Tri Yulianto, dan Sungkono, (2010), Pengaruh Unsur Nb Pada Bahan Bakar Paduan U-Zr-Nb Terhadap Densitas, Kekerasan Dan Mikrostruktur, Jurnal IImiah Daur Bahan Bakar "Urania”, Vol. 16 No. 3, Juli 2010. ISSN 0852-4777. Akreditasi No. 595/AU3/P2MI-LIPI/03/2015. Hal. 116.

[4] Masrukan K, M Husna Al Hasa, Anwar Muchsin, (2014), Pembuatan Green Pellet $\mathrm{U}-\mathrm{ZrH}_{\mathrm{x}}$ untuk bahan bakar PWR, Jurnal IImiah Daur Bahan Bakar Nuklir" Urania" . Vol 20 No 1, Febuari 2014. Halaman 23-24. ISSN No. 0852-4777. Akred. No. 265/AU1/P2MBI/05/2010.

[5] Rosika, Dian A, Agus J, (2010), Validasi Metoda XRF (X-Ray Fluorescence) Secara Tunggal Dan Simultan Untuk Analisis Unsur Mg, Mn Dan Fe Dalam Paduan Aluminum, Prosiding Seminar Nasional VI SDM Teknologi Nuklir Yogyakarta, 18 November 2010. ISSN 1978-0176. Hal. 273-277.

[6] ASTM C753-04, (2009), Standard Specification for Nuclear Grade, Sinterable Uranium Dioxide Powder, volume 12.01 Nuclear Energy (I).

[7] Sutri I, Yanlianastuti (2011), Analisis Serbuk U-Mo Untuk Pembuatan Pelat Elemen Bakar Dengan Tingkat Muat Tinggi, Seminar Nasional SDM Teknologi Nuklir VII, Yogyakarta, 16 November 2011. ISSN No. 1978- 0176. Halaman 563.

[8] Supardjo, Agoeng Kadarjono, Boybul, Aslina Br. Ginting, (2011), Pengaruh unsur Zr Terhadap Perubahan Sifat Termal Bahan Bakar Dispersi Paduan U-7Mo-xZr/AI, Jurnal Ilmiah Daur Bahan Bakar Nuklir "Urania", Volume 22 No. 1, Februari 2016, ISSN 08524777. Akreditasi No. 595/AU3/P2MILIPI/03/2015. Hal. 16.

[9] Aslina Br.Ginting, Supardjo, Sutri Indaryati, (2007), Pengaruh Porositas Meat Bahan Bakar Terhadap Kapasitas Panas Pelat Elemen Bakar $\mathrm{U}_{3} \mathrm{Si}_{2}-\mathrm{Al}$, 
Prosiding PPI-PDIPTN 2007, Pustek Akselerator dan Proses Bahan-BATAN, Yogyakarta, 10 Juli 2007. ISSN02163128. Halaman 130.

[10] Setiawan J, (2015). Sintesis Komposit Matriks Keramik Silikon Karbida Berbasis Polycarbosilane dan Karakteristik Panasnya Sebagai Bahan Penukar Kalor." Disertasi program S3, Universitas Indonesia, 2015. Halaman 41.

[11] Mariea Gruia, Ion Ciucă2, Marioara Abrudeanu, Tiberiu Meleg, Lulia Dumitrescu, (2013), Evaluation of
Physical Stability Of The U-ZrH System, Journal U.P.B. Sci. Bull., Series B, Vol. 75, Iss. 1. ISSN 1454-2331.

[12] Yu Sheng Chen, Adam I. Stasha, A. Alan Pinkerton, (2007), Chemical Bonding And Intermolecular Interactions In Energetic Materials: 1,3,4trinitro-7,8-diazapentalene, Journal Acta Crystallographica, ISSN No. 01087681. Page 309.

[13] Ivanov, Badaeva, Sofronova, (1983), Phase Diagrams of Uranium Alloys, Amerind Publishing Co.PVT.LTD, New Delhi. 


\section{LAMPIRAN}

Tabel 1. Data berat logam U, Zr dan ingot U-35Zr

\begin{tabular}{|c|c|c|c|c|c|}
\hline No & $\begin{array}{c}\text { Udeplesi } \\
(\mathrm{g})\end{array}$ & $\mathrm{Zr}$ & \% Zr & $\mathrm{U} \%$ & $\begin{array}{c}\text { Ingot U-35Zr } \\
(\mathrm{g})\end{array}$ \\
\hline 1. & 12,1585 & 6,50 & 35,00 & 65,00 & 18,6435 \\
2. & 12,7408 & 6,83 & 34,90 & 65,10 & 19,5659 \\
3. & 12,8993 & 6,85 & 34,54 & 65,46 & 19,7042 \\
4. & 12,3663 & 6,58 & 34,70 & 65,30 & 18,9425 \\
5. & 11,5278 & 6,15 & 34,77 & 65,23 & 17,6737 \\
6. & 11,1595 & 5,89 & 33,00 & 67,00 & 17,0533 \\
7. & 9,6805 & 5,89 & 39,64 & 60,36 & 14,8668 \\
\hline & Rat-rata & & $\mathbf{3 5 , 2 7}$ & $\mathbf{6 4 , 7 3}$ & \\
\hline
\end{tabular}

Tabel 2. Data berat logam $U, Z r$ dan ingot $U-45 Z r$

\begin{tabular}{|c|c|c|c|c|c|}
\hline No & $\begin{array}{c}\text { Udeplesi } \\
(\mathrm{g})\end{array}$ & $\mathrm{Zr}$ & $\% \mathrm{Zr}$ & $\mathrm{U} \%$ & $\begin{array}{c}\text { Ingot U-45Zr } \\
(\mathrm{g})\end{array}$ \\
\hline 1. & 10,4133 & 8,43 & 44,74 & 55,26 & 18,8437 \\
2. & 9,9278 & 7,83 & 44,11 & 55,89 & 17,7621 \\
3. & 9,5023 & 7,74 & 44,88 & 55,12 & 17,2343 \\
4. & 10,2558 & 8,34 & 44,86 & 55,14 & 18,5906 \\
5. & 9,7957 & 7,90 & 44,64 & 55,36 & 17,6945 \\
6. & 10,0509 & 8,16 & 44,81 & 55,19 & 18,2105 \\
7. & 10,3227 & 8,25 & 44,43 & 55,57 & 18,5762 \\
\hline & Rat-rata & & $\mathbf{4 4 , 6 4}$ & $\mathbf{5 5 , 3 6}$ & \\
\hline
\end{tabular}

Tabel 3. Data berat logam U, Zr dan ingot U-55Zr

\begin{tabular}{|c|c|c|c|c|c|}
\hline No & $\begin{array}{c}\text { Udeplesi } \\
(\mathrm{g})\end{array}$ & $\mathrm{Zr}$ & \% Zr & $\mathrm{U} \%$ & $\begin{array}{c}\text { Ingot U-55Zr } \\
(\mathrm{g})\end{array}$ \\
\hline 1. & 10,4147 & 12,69 & 54,92 & 45,08 & 23,1017 \\
2. & 10,5914 & 12,81 & 54,73 & 45,27 & 23,3959 \\
3. & 10,0407 & 12,23 & 54,91 & 45,09 & 22,2665 \\
4. & 7,5972 & 9,24 & 54,87 & 45,13 & 16,8341 \\
5. & 6,6807 & 8,22 & 55,15 & 44,85 & 14,8961 \\
6. & 6,1529 & 7,48 & 54,87 & 45,13 & 13,6342 \\
7. & 6,3221 & 7,70 & 54,90 & 45,10 & 14,0182 \\
\hline & Rat-rata & & $\mathbf{5 4 , 9 1}$ & $\mathbf{4 5 , 0 9}$ & \\
\hline
\end{tabular}


